\title{
Chapter 6 \\ People, Politics and Populism \\ in International Criminal Law: \\ The Mungiki as Kenyan Ethnos \\ and Kenyan Demos
}

\section{Edwin Bikundo}

'We the peoples of the United Nations'.

Preamble to the Charter of the United Nations

'My first draft was quite good, I thought. I'd based it on the UN Charter itself. The Foreign Office sent me over a copy, with a note attached explaining that the preamble to the Charter was known as the Unconditional Surrender of the English Language'.

The Complete Yes Prime Minister at 459

'if what humans speak is a language, and if there is not only one language but many, then the plurality of languages corresponds

to the plurality of people and political communities'.

Giorgio Agamben What is Philosophy? at 6

\section{Contents}

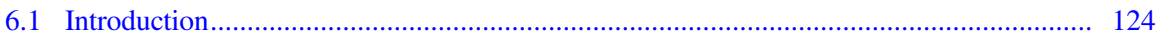

6.2 People in the United Nations Charter and International Criminal Law......................... 128

6.3 Female Circumcision and the Politics of Patriarchy …................................................ 130

6.4 The Faustian Pact, Political Violence and Law........................................................... 134

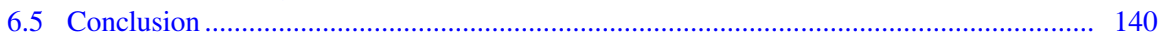

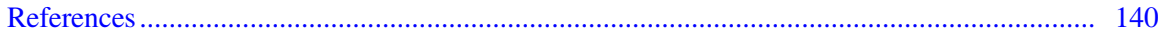

Abstract Although democracy and democratic practices, in the form of both direct and indirect public participation in governance are axiomatically a cherished value of liberal democratic principles, populism is nevertheless treated with wariness because

Edwin Bikundo is a Senior Lecturer at the Griffith Law School, Griffith University at the Gold Coast in Australia.

E. Bikundo $(\square)$

Griffith University, Gold Coast, Queensland, Australia

e-mail: e.bikundo@griffith.edu.au

(C) T.M.C. ASSER PRESS and the authors 2019

J. E. Nijman and W. G. Werner (eds.), Netherlands Yearbook

of International Law 2018, Netherlands Yearbook of International Law 49,

https://doi.org/10.1007/978-94-6265-331-3_6 
of its potential to come into conflict with other cherished values of liberal democratic principles such as human rights and the rule of law. The 'people' as such have a limited direct role ascribed in public international law. Therefore, populism for this chapter, references a crisis of political representation where a schism between a people and its representatives is detected, or claimed, or exploited. That so-called democratic deficit makes international criminal law practitioners on the one hand particularly vulnerable to demagogic speech challenging their legitimacy and on the other particularly tempted to counter demagoguery by asserting themselves as being more legitimate representatives of a victimised people than their oppressive rulers. This chapter consequently argues that in international criminal law the people is metaphorically explicable as an optical illusion appearing and disappearing at crucial moments in different guises. In the Kenyan case study selected, these contested guises include victims and popular mandates. The people as such are never present and yet remain politically as well as legally indispensable as a rhetorical claim to ground concrete action oriented towards justice.

Keywords Ethnos - Demos - Faustian pact - Giorgio Agamben - Max Weber • Monopoly on legitimate violence $\cdot$ Mungiki $\cdot$ Political violence $\cdot$ Populism

\subsection{Introduction}

Populism along with bigotry and xenophobia, according to the former President of the International Criminal Court (ICC) Judge Silvia Fernández de Gurmendi, have the potential to undermine 'international criminal justice and more broadly a rules based order'. 'John Dugard, concurred stating that '[a]t present the rule based international order is under threat from forces of nationalism and populism'. ${ }^{2} \mathrm{He}$ identified the UN Human Rights Council and the ICC as two principal targets of these nationalist and populist forces. At least one witness in The Prosecutor $v$. William Samoei Ruto and Joshua Arap Sang identified 'a certain degree of anti-Kikuyu populism' in the run-up to the 2017 elections in Kenya. ${ }^{3}$ Peter Kagwanja examined how 'the resurgence of populism and ethno-nationalism in the broader context of diffusion of 'informal' violence and widening inequality [...] sowed the seeds for the post-election violence, ${ }^{4}$ Kagwanja notes that:

\footnotetext{
${ }^{1}$ International Criminal Court, Judge Silvia Fernández de Gurmendi President of the International Criminal Court: Keynote remarks at plenary session of the 16th Session of the Assembly of States Parties to the Rome Statute on the topic of the 20th anniversary of the Rome Statute, 13 December 2017, at 4 .

2 Assembly of States Parties of the ICC, Speech by Professor John Dugard SC, Rome Statute 20 years - Addressing current and future challenges, 7 December 2018, at 1.

3 ICC, Transcript case The Prosecutor v. William Samoei Ruto and Joshua Arap Sang, ICC-01/09-01/11, 15 January 2016, at 63.

${ }^{4}$ Kagwanja 2009, at 366.
} 
Populism in Kenya has a long history in the struggle against colonialism and one-party tyranny. ... Like their global contemporaries, Kenya populists drew a sharp divide between 'the people' and 'the elite' and rhetorically appealed to change in the political order while invoking the idea of democracy as, above all, an expression of the people's will. ${ }^{5}$

Cas Mudde and Cristóbal Rovira Kaltwasser define populism as 'as a thin-centered ideology that considers society to be ultimately separated into two homogeneous and antagonistic camps, "the pure people" versus "the corrupt elite," and which argues that politics should be an expression of the volonté générale (general will) of the people'. ${ }^{6}$ Mudde and Kaltwassser examine North America, South America, Eastern Europe and Western Europe but omit Africa from their analysis neither do they address the question of violence in the context of populism. This chapter will use the work of Italian philosopher Giorgio Agamben to analyse the Mungiki as a case study, in order to argue that Mungiki are populist purveyors of political violence above all else. Agamben is useful with regard to his work on the 'oath', the idea of a 'people', among others which is of unique explanatory power with regard to the Mungiki case study. The Mungiki poses a significant populist challenge to International Criminal Law (ICL) given the failure to successfully repress and prosecute the phenomenon of Mungiki despite the considerable time, effort and resources deployed.

On 23 September 2011, during Francis Muthaura's Pre-Trial hearing for crimes against humanity before the ICC, his legal counsel Karim Khan said:

Your Honours, another essential plank of this Prosecution's case is what can only be described as an unholy alliance, a deal with the devil, between the government and [sic] Kenya and a criminal, a lamentable, an invidious criminal group called the Mungiki. ${ }^{7}$

Describing the Mungiki as criminal was far from unusual, assimilating them to the devil however was less so. Why did counsel Khan reach for the religious and literary metaphor of a 'deal with the devil' to express himself in the context of a trial? In one sense Khan was in good company however as even Philip Alston the then Special Rapporteur on Extrajudicial, Summary or Arbitrary Executions, had described them as a criminal organisation that begun as a cultural-religious movement and even provided basic services including sanitation and security to the poor in slum areas. ${ }^{8}$ What is more, Mungiki members were both perpetrators and victims of serious crimes including murder both by the police and at the hands of vigilante groups (one of which, Alston notes, went by the moniker of 'The

\footnotetext{
${ }^{5}$ Ibid.

${ }^{6}$ Mudde and Kaltwasser 2013.

7 The Prosecutor vs Francis Kirimi Muthaura, Uhuru Muigai Kenyatta, and Mohammed Hussein $A l i$, ICC Pre-Trial Chamber II, Confirmation of Charges Hearing, ICC-01/09-02/11, Court Transcript at 67.

8 UN Human Rights Council, Report of the Special Rapporteur on extrajudicial, summary or arbitrary executions Mr Philip Alston: Addendum - Mission to Kenya, A/HRC/11/2/Add.6, 26 May 2009, at 7.
} 
Hague'). ${ }^{9}$ Alston's report on 'Extrajudicial, Summary or Arbitrary Executions' on his Mission to Kenya formed part of the court record in the Kenyan situation before the ICC.

The Mungiki have been accused of engaging in cyclical political violence in Kenyan elections 'either as an intimidatory force (or political militia) operating prior to elections, or as perpetrators of retaliatory attacks (as in the 2007 post-election violence)'. ${ }^{10}$ The campaign debate in the lead up to the post-electoral violence ' $[\ldots]$ took a populist turn that paved the way for the ethnic violence after the elections', in which both sides were complicit. ${ }^{11}$

However, it is not the undeniable fact that the Mungiki engaged in routine criminal activity, nor that they participated in both licit and illicit activities, nor even that they were simultaneously perpetrators and victims of international crimes that is the subject of this chapter. Instead what guides the present inquiry is that etymologically, the word 'Mungiki', in the Kikuyu tribal language from which community they principally draw their membership is translatable to mean 'people' as a properly undifferentiated mass. ${ }^{12}$ Grace Nyatuga Wamue has noted its close proximity in meaning to 'crowds' as well as 'masses' and that it: '[...] reflects a belief that people are entitled to a particular place of their own in the ontological order. The term therefore means 'fishing the crowd from all corners of Kenya'. Mungiki also refers to a religio-political movement composed mainly of large masses of Gikuyu origin and other non-Gikuyu (Pokots, Luos and Maasais)'. ${ }^{13}$ Jacob Rasmussen concurs with Wamue's view that '[i]n Kikuyu, Mungiki means "multitude" or "masses"; the name powerfully communicates the movement's ambition of reaching out not only beyond the Kikuyu tribe, but also potentially beyond Kenya and Africa'. ${ }^{14}$ This aggressive mobilisation of the Kikuyu simultaneously as ethnos and demos against the spectre of both internal and external enemies with the Mungiki cast in the role of saviour through purificatory violence is what this chapter understands as populism in the Kenyan context. Here the Mungiki (in common with populists the world over) toy with in Agamben's terminology membership (being present) of a group versus inclusion in a group (being merely re-presented). ${ }^{15}$ The stated aim of the Mungiki since their origins in the 1980s, has been both to revive indigenous Gikuyu culture and religion, and to liberate the Kenyan masses from political oppression and economic exploitation. ${ }^{16}$ As Rasmussen notes, '[t]he movement's founders, and its adherents more generally, claim a specific heritage from the Mau Mau, Kenya's freedom fighters of the

9 Ibid., at 8 n 12 .

10 Rasmussen 2010.

11 Harneit-Sievers and Peters 2008, at 136.

12 Wamue 2001, at 454.

13 Wamue 2001, at 454.

14 Rasmussen 2010.

15 Agamben 1998, at 24.

16 Ahlberg and Njoroge 2013. 
1950s'. ${ }^{17}$ Mungiki glide, navigate and oscillate between them as a Kikuyu-linked ethnos which is to say they are a population group sharing a common descent, and cultural tradition as well as a demos which by contrast is people organised as a polity usually by some form of democratic practice.

This last aspect is what renders the Mungiki a fit and proper subject of inquiry as a strain of African populism in a peculiarly Kenyan international criminal law context. As Sinja Graf has ably demonstrated 'the concept of crimes against humanity [...] in the Rome Statute of the International Criminal Court criminalizes forms of direct, physical violence and thus excludes institutional and structural versions of violence from the range of practices that offend humanity'. ${ }^{18}$ This blind spot excluding institutional and structural forms of violence as identified by Graf is what this chapter tries to remedy particularly focusing on cultural and bodily violence perpetrated on women via the practice variously described as female circumcision/clitoridectomy/female genital mutilation/Irûa in the Kikuyu language (incorporating both female and male circumcision). This chapter will use the descriptive term 'female circumcision' combining as it does a communal practice incorporating both physical and ritualistic aspects that the medicalized 'clitoridectomy', condemnatory 'female genital mutilation' and approbatory Irûa do not adequately capture. This is done to demonstrate how an understanding of the central role of the practice is essential to link the key Mungiki characteristics (like the historical Mau Mau movement from which they trace their genealogy from) of an anti-Western ideology that projects itself as an emancipatory force fixated on land and engages in political violence as a means to that end. Furthermore, Mutuma Ruteere has made the compelling argument 'that rather than being one organization, Mungiki has become a discourse, invoked by different groups whether in authority or other criminal gangs to achieve particular ends'. ${ }^{19}$

Following this introduction, the first part of the chapter looks at how the term 'people' is treated in international criminal law and how Mungiki as a phenomenon is not something the apparatus of international law was designed to deal with, the second part develops a theoretical and conceptual framework based on the work of Giorgio Agamben to come to grips with this phenomenon of Mungiki that is at once criminal, cultural, religious, economic, political, violent and above all for the purposes of this chapter founded on the subjugation of women's bodies and their simultaneous sidelining as active political subjects. That analysis is accomplished through categories derived from Aristotle's Politics by Giorgio Agamben including oikos or home, polis or city as well as stasis or civil war and finally amnesty. The third part looks at why the ICC grappled unsuccessfully with this unique and challenging strain of populism. The fourth section teases out why and how counsel Khan above would have reached for the devil as an apt metaphor to describe such practitioners and purveyors as well as victims of political violence as Mungiki and

\footnotetext{
17 Rasmussen 2010.

18 Graf 2017.

19 Ruteere 2008, at 23-24.
} 
in that way resisted his client being cast as an Africanised Faust. The conclusion brings all the threads together summarising and explaining what the inquiry has addressed, uncovered and suggests going forward.

\title{
6.2 People in the United Nations Charter and International Criminal Law
}

Why would a multi-faceted movement that, among other things, engages in political violence name themselves as literally 'the people' or 'the masses', if not to politicise itself and in that way somehow legitimate itself as other than criminal? This section thus seeks to demonstrate that, by equating themselves with that elusive concept of 'the people', Mungiki quite self-consciously seek to politically justify their use of violence as a legitimate emancipatory tool. To start with what the umbrella term 'people' covers in the context of Mungiki, Rasmussen notes that:

\begin{abstract}
Since its inception Mungiki has been classified in a variety of ways: as a new religious and neo-traditionalist movement or occult sect, as a social movement or political party, and as a criminal gang or political militia. Though the importance of several of these labels has been overemphasised in the past, each contains some truth, a fact which indicates the movement's multilayered and multifaceted character. Its relatively large membership base, its extensive regional coverage (its members are drawn from both remote rural areas and densely populated urban neighbourhoods), and the many facets of the movement combine to make Mungiki a highly heterogeneous organisation. ${ }^{20}$
\end{abstract}

We can begin to make more sense of Mungiki's high heterogeneity by more closely analysing the term people first in the context of international law and subsequently by engaging with Italian political philosopher's Giorgio Agamben's philological work on the term. At the outset, the customary international law definition of a 'State' includes the key criteria of population (as well as territory, government and capacity to enter into relations with other States) but makes no explicit mention of 'people' as such. ${ }^{21}$ This is perfectly congruent with the UN Charter's preamble which opens with the phrase 'We the Peoples of the United Nations' with the term 'peoples' again used to reference 'the populations of the member States'. ${ }^{22}$ It needs careful noting that this is not the uniform meaning of 'peoples' - not even in the Charter itself with, for example, 'peoples' bearing an ethnic connotation in Article 1(2) immediately following the Preamble. $^{23}$ Furthermore, out of a total of only twelve references to 'peoples', two are in the Preamble, another two are with explicit reference to self-determination and the eight

\footnotetext{
20 Rasmussen 2010.

${ }^{21}$ See Montevideo Convention on the Rights and Duties of States (1933), 165 LNTS 19 ('Montevideo Convention'), Article 1.

22 Wolfram (2012), at 103.

${ }^{23}$ Ibid.
} 
others remaining are in the two chapters to do with the 'Declaration Regarding Non-Self-Governing Territories' and the now defunct 'International Trusteeship System'. That defunct Trusteeship system moreover has the sole mention of 'people' in the entire Charter. Suffice to say the simultaneous overlap and distinction between population and people locates a population as an apolitical construct that is politically amenable to be constituted within a State while 'people' is politically instituted in and of itself whether inside or outside the State. There is therefore scant scope for recognition of Mungiki in public international law as currently constituted because the 'people' that would be recognisable would be the Kikuyu people and not Mungiki as such who would at best be a political movement dominated by without being exclusively of the Kikuyu as a vehicle for populist politics.

International criminal law on the other hand references 'people' at various points including the International Military Tribunal for the Major War Criminals of the European Axis (IMT) Nuremberg Charter which only twice talks of 'civilian population' in the context of victims of war crimes and crimes against humanity but otherwise has nothing to say explicitly on people as such. Likewise, the International Military Tribunal for the Far East (IMTFE) Tokyo Trial Charter is silent on 'people' but does reference 'civilian population' once, in relation to crimes against humanity. This is the approach followed by the International Criminal Tribunal for the former Yugoslavia (ICTY), as well as the International Criminal Tribunal for Rwanda (ICTR) Statutes with their sole reference to 'civilian population', and also only in relation to crimes against humanity. The ICTR does however include a reference to 'civilised peoples' which the ICTY lacks. Furthermore, the ICTR's case law in Akayesu contributed the notion of 'any stable and permanent group' as being protected under the Genocide Convention. ${ }^{24}$ The Rome Statute for the ICC is broader than all the preceding examples. Its Preamble opens with a reference to 'all peoples' and goes on to refer to population twelve times with regard to both war crimes and crimes against humanity. However, because individual criminal responsibility and not group responsibility is the rule, there is limited scope for international criminal law to directly deal with a phenomenon like Mungiki beyond the 'group of persons acting with a common purpose' meaning. ${ }^{25}$ It is not just the UN Charter generally nor international criminal law in particular that have difficulty in finding purchase on the term 'people' but also political theory and practice.

In his essay, 'What is a people?', Italian philosopher Giorgio Agamben, begins by highlighting and demonstrating how 'people' in numerous examples also indicates 'the poor, the underprivileged, and the excluded'. ${ }^{26}$ That is it has the effect of connoting both the politically active subject as well as those that are excluded as

\footnotetext{
${ }^{24}$ Prosecutor v. Akayesu, ICTR, Judgement, ICTR-96-4-T, 2 September 1998, para 516.

25 See Rome Statute for the International Criminal Court (1998), 2187 UNTS 90 ('Rome Statute'), Article 25.

26 Agamben 2000, at 29.
} 
anything other than abject, passive subjects. He goes on to claim though that this ambiguity is no accident but rather 'reflects an ambiguity inherent in the nature and function of the concept of people in Western politics'. This would make 'people' an 'oscillation between two opposite poles' not a unitary subject. ${ }^{27}$ This also maps it into Agamben's most famous conceptual pair zoë or 'naked life' represented in people and bios or political existence representing People. ${ }^{28}$

In contrast to the UN Charter the international criminal law examples do not make reference to 'people' in the sense of a politically active population that is recognised as such but rather as an abject population always and invariably in need of protection, and in no way directly present except as a void to be filled by humanitarian action. This is why populism here then references a crisis of political representation where a schism is detected or claimed between the people and their rulers. Where people are always spoken of but excluded because they are already spoken for. In the next section, this chapter will go on to argue that populism pushes a form of illiberal democracy where human rights and the rule of law are sacrificed for political expediency in the name of the people but really in the service of populism. Nothing illustrates this better than the position of women with regard to the Mungiki movement as we shall see presently.

\subsection{Female Circumcision and the Politics of Patriarchy}

This section will develop and build on Graf's insight above, that there are certain constitutive elements of structural violence (in this specific instance symbolic as well as physical violence against women) that are rendered invisible in the ICC's practice. To start with, Beth Maina Ahlberg and Kezia Muthoni Njoroge have noted that the Mungiki are a predominantly young and predominantly male association generally speaking. ${ }^{29}$ Furthermore, there are no female leaders anywhere prominent in its ranks. Notwithstanding that (or perhaps better as a result of that) the subjectification and subjugation of women is as we shall see a key plank in its strategies: '[t]hey have, for example, attacked women deemed improperly dressed for wearing trousers which in turn has led to public outcry against them'. ${ }^{30}$ As Ahlberg and Njoroge note, 'one of its philosophies is to reinstate female genital cutting which has declined, as a result of which, Mungiki argues, society's good values have also declined'. ${ }^{31}$ Neither consistency nor coherence of doctrine however are Mungiki's strong suit as seen for instance during its rampages: 'Men rather than women were hunted down and forcibly circumcised or had the penis cut or

\footnotetext{
27 Agamben 1998, at 177.

28 Agamben 1998, 2005, 2011.

29 Ahlberg and Njoroge 2013.

30 Ibid.

31 Ahlberg and Njoroge 2013.
} 
mutilated, sustaining long-lasting, and debilitating injuries, ${ }^{32}$ Mungiki - through symbolic and physical violence - essentially in the name of protecting women subsume women into men. It then follows that up with progressively blurring the lines between Kikuyus, Kenyans and Africans generally.

Wamue notes that although the Mungiki is almost entirely a Kikuyu phenomenon it has the ambition to embrace the Kenyan tribes through a shared African heritage involving 'a return to issues like female genital mutilation, sacrifices, oaths, and such outdated customs'. ${ }^{33}$ Agamben situates the oath 'at the intersection of law and politics ${ }^{34}$ and notes its 'essential function' in the political constitution. ${ }^{35}$ Agamben furthermore, obliquely references circumcision always and only in relation to belonging to a specific community. ${ }^{36}$ This is the significance then of female circumcisions to Mungiki's populism or quasi-populism.

Wamue, states that 'Mungiki followers insist that their sect does not advocate the physical act of circumcision per se, but the moral grounding that is associated with the traditional rite'. ${ }^{37}$ Mungiki further 'assert that less than 10 percent of Mungiki women are circumcised and that no one is insisting that they undergo circumcision' ${ }^{38}$ Jacob Rasmussen also states that 'Mungiki no longer advocate clitoridectomy' after noting that at the beginning Mungiki were of the view that 'many Kenyans operated with a fundamentally colonial mindset and needed to have their minds freed through a return to traditional religious and cultural values, including female circumcision'. Nevertheless, the practice does persist with Wairimu Ngaruiya Njambi self-reporting that:

While the cultural significance of female circumcision has been waning in the past few decades, due mainly to church pressures, its cultural importance was still strong enough during my youth that I saw it as a necessity. It may seem ironic, given the tales of 'flight from torture' told in the media, but my parents refused to allow me to be circumcised, as it was against Catholic teachings. I had to threaten to run away from home and drop out of school before my parents relented and allowed me to be circumcised. The procedure was performed with a medical scalpel in a local clinic run by a woman who was a trained nurse in the western sense, and also a relative of an important Gikuyu female medical healer and powerful leader of the early 20th century, Wairimu Wa Kinene. During the operation, the hood of the clitoris was cut through its apex which caused the hood to split open and the clitoris to become more completely exposed. Such exposure has been associated with sexual enhancement. However, any generalization here might be unwise as it is likely that women's experience of irua [circumcision] varies, perhaps significantly. ${ }^{39}$

32 Ibid.

33 Wamue 2001.

34 Agamben 2011, at 1.

35 Agamben 2011, at 2.

36 Agamben 2005, at 19, 21, 45, 165 and 176.

37 Wamue 2001.

38 Ibid.

39 Njambi 2004. 
As already indicated on the literature surveyed above, the aim of the Mungiki since the 1980s, was to leverage religion for political and economic gains, to not 'only revive indigenous Kikuyu culture and religion, but also to liberate the Kenyan masses from political oppression and economic exploitation'. ${ }^{40}$ With this background we can now focus on the main objective of the Mungiki, which is allegedly to unite and mobilize the Kenyan masses to fight against the yoke of mental slavery to 'foreign cultures and agents of those cultures among the Kikuyu'. ${ }^{41}$ It needs to be noted in the first instance that 'Despite their Kikuyu heritage, the Kenyatta family are thus among the main offenders in what Mungiki perceive as "historical injustices" to the Mau Mau and their kin'. ${ }^{42}$ In other words (just like the Mau Mau before them) the Mungiki are very much an intra-Kikuyu phenomenon approximating a class conflict akin to civil war between the descendants of the Kikuyu Peasantry and the Kikuyu aristocracy. ${ }^{43}$ This civil war nourishes Mungiki's populism in that it can claim to be fighting internal (fellow Kikuyu) and external (potentially anyone and everyone else) enemies of the Kikuyu simultaneously. Indeed the vast majority of Mungiki victims are Kikuyus, a fact that was unacknowledged in the ICC proceedings given its specific focus on Mungiki's violence against other groupings and tribes. Having said that this intra-Kikuyu civil war is significant in understanding the context of Mungiki's operations.

The theses Agamben advances in Stasis: Civil War as a Political Paradigm ${ }^{44}$ are first, that civil war is the threshold between politicisation and de-politicisation (at least in the West) and second, that the constitutive element of the state is the absence of a people. ${ }^{45}$ Agamben goes on to note that 'a theory of civil war is completely lacking today' where 'hand in hand with the advance of global civil war' academic analysis is geared 'toward the conditions under which an international intervention becomes possible'. ${ }^{46}$ His lament is that this 'seems incompatible with the serious investigation of a phenomenon that is at least as old as Western democracy'. ${ }^{47}$ His work however does not purport to fill this gap on its own. Rather, it restricts itself to examining stasis (treated as synonymous with civil war) in Ancient Greece and in Thomas Hobbes's work as representing 'two faces' ... 'of a single political paradigm' being 'the necessity of civil war' simultaneously with 'the necessity of its exclusion' both of which mutually 'maintain a secret solidarity' that Agamben 'seek[s] to grasp'. ${ }^{48}$

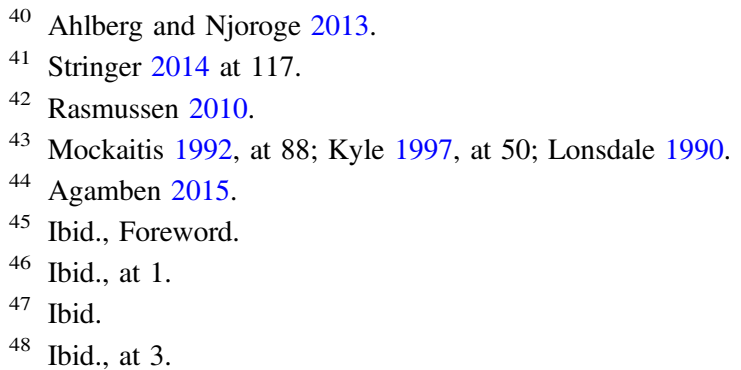


The notion of stasis 'constitutes a zone of indifference between the unpolitical space of the family and the political space of the city'. ${ }^{49}$ For Agamben 'in Greek politics civil war functions as a threshold of politicisation and depoliticisation, through which the house is exceeded in the city and the city is depoliticised in the family, ${ }^{50}$ Agamben cites that Greek law, under Solon, the Athenian lawmaker, punished 'the citizen who had not fought for either one of the two sides in a civil war with the loss of civil rights'. ${ }^{51}$ Therefore 'not taking part in civil war amounts to being expelled from the polis and confined to the oikos, ${ }^{52}$ Per Agamben, according to Aristotle:

the invention of amnesty [...] with respect to civil war is thus the comportment most appropriate to politics. From the juridical point of view, stasis thus seems to be defined by two prohibitions, which perfectly cohere with one another: on the one hand, not participating in it is politically culpable; on the other, forgetting it once it has finished is a political duty. ${ }^{53}$

Rather provocatively, this is 'just the opposite, that is to say, of what civil war seems to be for the moderns: namely, something that one must seek to render impossible at every cost, yet that must always be remembered through trials and legal prosecutions' ${ }^{54}$ It is fully evident that in contrast to amnesty, repressing Mungiki 'only makes its followers more determined and violent ${ }^{55}$ Indeed Agamben concludes the analysis with: 'stasis, which can no longer be situated in the threshold between the oikos and the polis, becomes the paradigm of every conflict and re-emerges as terror. ${ }^{56}$

Although he perhaps deems it too obvious to mention, Agamben's starting point of the centrality of civil war to Hobbes' state of nature is strengthened by the historical fact that Leviathan was conceived in and responded to the context of the English Civil War. ${ }^{57}$ For Agamben the mortal god leviathan 'does not dwell within the city, but outside it ${ }^{58}$ Further the city is devoid of its inhabitants. ${ }^{59}$ The iconic image thus discloses that 'political representation is only an optical representation (but no less effective on account of this) ${ }^{60}$ Indeed 'at the very instant that the people chooses the sovereign it dissolves into a confused multitude'. ${ }^{61}$

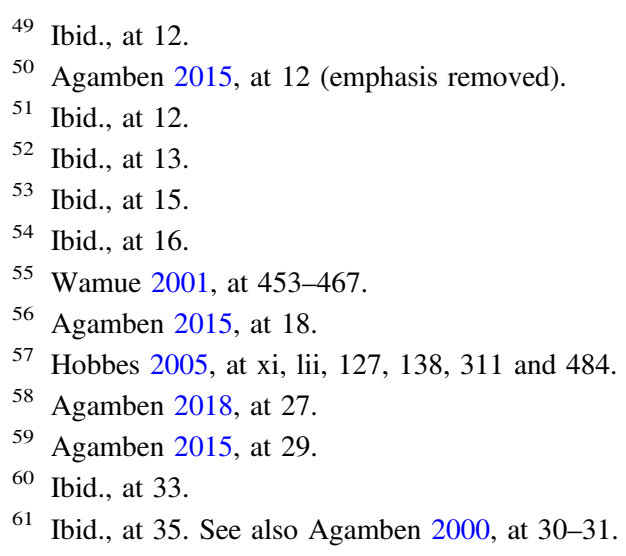


Consequently, 'the state of nature is the city from the perspective of civil war'. ${ }^{62}$ Previously, in dialogue with Walter Benjamin and Carl Schmitt, Agamben has described this oscillation as between 'constituent power and constituted power'. ${ }^{63}$ To put it more emphatically, 'the state of nature is a mythological projection into the past of the civil war; conversely, civil war is a projection of the state of nature into the city: it is what appears when one considers the city from the perspective of the state of nature'. ${ }^{64}$ Furthermore, 'political theology appears in Hobbes in a decidedly eschatological perspective'. ${ }^{65}$ For Agamben, 'it is certain that the political philosophy of modernity will not be able to emerge out of its contradictions except by becoming aware of its theological roots'. ${ }^{66}$

Agamben's work does delve deeply into theological concepts but the focus is more on their strategic deployment rather than their systematic development over time. ${ }^{67}$ As such it is always political theology in the Schmittian sense. In the context of the law's complicity with violence generally this is a political theodicy very much in the vein of his treatments of the Faustian pact which is located at the intersection of philosophy, law and religion. The Mungiki as purveyors of political violence fall squarely within this formulation as we shall see presently below. As Agamben's analysis has made it possible to see violence is included in the juridical order as either sanctioned in the sense of permitted or sanctioned in the sense of not permitted. ${ }^{68}$ This perfect ambiguity and dual valence of 'sanction' in law is key to the riddle of law's reliance upon and repressing of violence.

\subsection{The Faustian Pact, Political Violence and Law}

Mungiki's rise in influence and popularity in part depended on the 'the inability of the Government to demonstrate its monopoly over violence for the common good' ${ }^{69}$ Given their use of violent means, Mungiki pose a conscious, clear, direct and deliberate threat to the Kenyan state's Weberian claim to 'the monopoly on the legitimate use of physical violence' within Kenyan territory. ${ }^{70}$ Writing in the period following Germany's defeat in the First World War (and while resisting the notion of a collective 'war guilt') Max Weber set out his task in Politics as a Vocation as an attempt to sociologically define a political association and stated that: 'in the

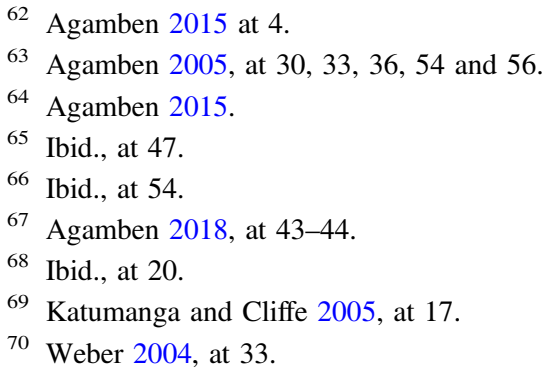


final analysis, the modern state can be defined only sociologically by the specific means that are peculiar to it, as to every political association: namely, physical violence'. ${ }^{71}$ Furthermore he went on to add that: 'If there existed only societies in which violence was unknown as a means, then the concept of the 'state' would disappear; in that event what would have emerged is what, in this specific meaning of the word, we might call 'anarchy'. ${ }^{72}$ Weber did add the proviso that: 'Violence, is of course, not the normal or the only means available to the state [...] But it is the means specific to the state ${ }^{73}$ Derrida summarized this as, 'At its most fundamental level, European law tends to prohibit individual violence and to condemn it not because it poses a threat to this or that law but because it threatens the juridical order itself. ${ }^{, 74}$ Further, 'Law has an interest in a monopoly of violence to protect neither justice nor legality but law as such. ${ }^{75}$

Weber's rightly famous passage defining the State deserves contextual quotation to demonstrate the stakes of Mungiki's political violence in its challenge to the Kenyan State apparatus:

In the past the use of physical violence by widely differing organisations - starting with the clan - was completely normal. Nowadays, in contrast, we must say that the state is the form of human community that (successfully) lays claim to the monopoly of the legitimate use of physical violence within a particular territory - and this idea of 'territory' is an essential defining feature. For what is specific to the present is that all other organisations or individuals can assert the right to use physical violence only insofar as the state permits them to do. The state is regarded as the sole source of the 'right' to use violence. Hence, 'politics' for us means to strive for a share of power or to influence the distribution of power, whether between states or between the groups of people contained within a state. ${ }^{76}$

Less well known and less quoted moreover is that in the same place Weber said that: 'Anyone who wishes to engage in politics at all [...] is entering into relations with satanic powers that lurk in every act of violence'. ${ }^{77}$ For removal of doubt Weber even goes on to quote the same passage of Goethe's Faust in Politics as a Vocation as well as Science as a Vocation: 'Reflect, the Devil is old, so become old if you would understand him'.${ }^{78}$ Given the irresistible logic that political science as a discipline would have to be located at the centre of the Politics as a Vocation/ Science as a Vocation axis the value of the Faustian pact as an explanatory framework for international criminal law's relationship to violence becomes increasingly clear. Namely, the analysis of that Mephistophelean pact analogy demonstrates that it is based on excusing otherwise evil acts by arguing that that

71 Weber 2004, at 33 (emphasis in original).

72 Ibid.

73 Weber 2004, at 33.

74 Derrida 1990, at 987.

75 Ibid.

76 Weber 2004, at 33.

77 Weber 2004, at 90

78 Ibid., at 27 n 27 and at 91 n 87. 
evil will nevertheless promote good. Which is to say the socio-legal legitimation of violence links good to evil in purportedly productive ways. Giorgio Agamben speculates on a behind the scenes and covert engagement between Walter Benjamin and Carl Schmitt concerning a battle of these prominent intellectuals over the void that is the state of exception where nothing is forbidden and the law is neutralized. ${ }^{79}$ Which is to say where the force that usually accompanies law is freed up of the law's strictures. Furthermore that decoupling of force from law is legitimated and justified in the name of emergency measures that are then progressively normalized.

Writing in the wake of Weber, Walter Benjamin in his 'Critique of Violence' sets out his own purpose as explicating the relationships between violence and law and justice:

The task of a critique of violence can be summarized as that of expounding its relation to law and justice. For a cause, however effective, becomes violent, in the precise sense of the word, only when it bears on moral issues. The sphere of these issues is defined by the concepts of law and justice. With regard to the first of these, it is clear that the most elementary relationship within any legal system is that of ends to means, and, further, that violence can first be sought only in the realm of means, not of ends. ${ }^{80}$

Benjamin's own view of Weber's monopoly of violence as the specified means available to the State is instructive with regard to the political challenge directed to the Kenyan legal order (which view coheres perfectly with Derrida's as noted above because it was indeed the basis upon which Derrida relied):

the law's interest in a monopoly of violence vis-à-vis individuals is not explained by the intention of preserving legal ends but, rather, by that of preserving the law itself; that violence, when not in the hands of the law, threatens it not by the ends that it may pursue but by it mere existence outside the law. ${ }^{81}$

Schmitt also writing in the wake of Weber's secularization thesis famously said that it was sociologically necessary to consider that 'All significant concepts of the modern theory of the state are secularized theological concepts'. ${ }^{82}$ This was according to him 'because of their historical development' (he provides the example of a theological 'omnipotent God' reasserted as the political 'omnipotent lawgiver'). ${ }^{83}$ Schmitt makes no mention of the Faustian pact here but the same logic would follow as we shall see presently when we return to 'the deal with the devil' that was referenced with regard to Mungiki.

The precise contours of 'the deal with the devil that counsel Khan referred to were that Uhuru Kenyatta mediated between his political party the Party of National Unity (PNU) and Mungiki, in order to organise retaliatory attacks against the rival political party the Orange Democratic Movement (ODM) in order to consolidate

\footnotetext{
79 Agamben 2005 52-64.

80 Benjamin 1978, at 277.

81 Ibid., at 280-281.

${ }^{82}$ Schmitt 2005 at 36.

${ }^{83}$ Ibid.
} 
PNU's hold on power. ${ }^{84}$ In return, the allegation was that, Kenyatta in concert with others 'provided funding, transportation, accommodation, uniforms, weapons and logistical support to the Mungiki and pro-PNU youth to carry out coordinated attacks in specific locations', additionally, they guaranteed safe passage with the knowing connivance of the police to not intervene both before and after attacks. ${ }^{85}$ Essentially therefore the pact was for Mungiki to provide political violence in exchange for funding, support and facilitation. Put simply the Mungiki marketized their capacity for actual and symbolic political violence and were recompensed in return.

Rasmussen has noted that '[o]ne of Mungiki's central political demands has been for a generational transfer of power, a demand rooted in the Kikuyu tradition, itwika, according to which an older generation hands over power to a younger generation in a 30-40 year cycle'. ${ }^{86}$ This demand has led to Machiavellian struggle between the state and the movement in a game of bluff, double bluff and even triple bluff that Rasmussen ably conveys and summarises as 'while Mungiki officially declared its support for Kenyatta and Moi [in the 2002 elections], in reality it supported the opposition candidate, Mwai Kibaki' ${ }^{87}$

To start with the bluff it began with then President Daniel arap Moi anointing Uhuru Kenyatta as his successor (and in that way having him as the sole viable Kikuyu candidate - a plan that was scuttled by prominent Luo leader Raila Odinga supporting Mwai Kibaki a Kikuyu who ultimately and unexpectedly won) in order to manipulate the large and recalcitrant Kikuyu voting bloc into aligning with this line of succession and power transfer:

For Mungiki, Uhuru Kenyatta (son of Kenya's first President after independence, Jomo Kenyatta) was a bad choice. He was widely known as "a spender", a businessman with little political experience and, more controversially, he represented the Kenyatta family, who in Mungiki's eyes had betrayed their ancestors, the Mau Mau, at independence. It seems clear that Moi was trying to sell an ethnic Kikuyu leader to Mungiki in return for the votes of young Kikuyu that the movement could guarantee. But Mungiki's leader, Maina Njenga, had political ambitions of his own and wanted to run for parliament. The problem, as Muigai presents it, was that both Uhuru Kenyatta and Maina Njenga wanted the votes of the Kikuyu youth, but that Njenga (unlike Uhuru) had a massive organised following in the traditionally Kikuyu-dominated regions of the country.

The double bluff arose because the Mungiki saw clearly through Moi's scheme and its motivations and as a consequence took steps to neutralise these machinations:

\footnotetext{
84 The Prosecutor vs Francis Kirimi Muthaura, Uhuru Muigai Kenyatta, and Mohammed Hussein Ali, ICC Pre-Trial Chamber II, Public Redacted Version Decision on the Confirmation of Charges Pursuant to Article 61(7)(a) and (b) of the Rome Statute, at paras 289-295.

85 Ibid.

${ }^{86}$ Rasmussen 2010.

87 Ibid.
} 
Mungiki suspected that Moi was playing a double game whereby he would gain the support of Mungiki's Kikuyu supporters for the election while simultaneously creating tension between Uhuru and Mungiki that would later allow Uhuru to denounce the movement.

Mungiki's response was the triple bluff which may be summarised as 'The movement's hidden strategy was to declare its public support for Uhuru Kenyatta, thus denying him the votes of ordinary Kikuyu voters alarmed by Mungiki's violent reputation, while secretly directing its own members to vote for the opposition just one week before the elections'. ${ }^{88}$ As seen below:

\begin{abstract}
Mungiki decided to cooperate with Moi and publicly support Uhuru Kenyatta. On one occasion, the movement organised a large fundraising event, attended by 10,000 people, in support of Uhuru. On another, Mungiki held a large prayer meeting in a field belonging to Uhuru (although Mungiki made it appear as though the proceedings had Uhuru's blessing, the event took place without his knowledge). The idea was to discredit Uhuru by making strategic use of Mungiki's own bad reputation; by associating him with the movement and with the political violence it had come to represent, Mungiki sought to scare off Uhuru's potential voters. The motivation for this strategy was to secure the election of the presidential candidate that the Mungiki leadership actually wanted: Mwai Kibaki. It also offered the opportunity for Mungiki to get its revenge on both Moi, who had mounted brutal police campaigns against the movement, and on Kenyatta, who represented the family widely blamed for the historical injustices that the movement and its followers claimed to have suffered.
\end{abstract}

Furthermore, following this government, 'launched a police crackdown on the movement and created special units to infiltrate its ranks' ${ }^{89}$ To add to the murkiness of distinguishing between real and simulated Mungiki action, Peter Kagwanja argues that Mungiki's allegations of State infiltration by police agents and even of state-sponsored pseudo gangs masquerading as Mungiki should not be taken lightly. ${ }^{90}$ This is particularly so when similar tactics were deployed by the British colonial State against the Mau Mau which is the template followed here. ${ }^{91}$ What is not seriously in doubt however is the Mungiki commoditised their capacity to unleash real and symbolic violence for both commercial and political ends.

Resort to violence is essentially then a Faustian pact by way of conceiving of violence as inherently evil but nevertheless capable of achieving good when opposing violence. In Goethe's Faust, Faust asks Mephistopheles: 'Who are you then?' and is answered perhaps truthfully but not completely honestly: 'Part of that force which would do ever evil, and does ever good.'92 As Walter Benjamin pointed out, distinguishing between law making or law preserving violence leaves the question of violence itself untouched and unquestioned. ${ }^{93}$ The prevailing test is only violence as a means to an end, and therefore, in this way violence is only to be

\footnotetext{
88 Rasmussen 2010.

89 Ibid.

90 Kagwanja 2005, at 41-42.

91 Ibid.

92 Goethe 2001, at 36.

93 Benjamin 1978, at 277.
} 
evaluated strictly as a means, a so-called necessary evil whose evil is undisputed but necessity is impossible to prove or disprove.

For Agamben, 'the law consists of essentially in the production of a permitted violence, which is to say in a justification of violence'. ${ }^{94}$ He discusses two paradigms in Western ethical and political thought that are especially critical to the 'unwilling and unable' pairing in the ICC's complementary jurisdiction. The first 'tragic' model is based on action and praxis while the second is anti-tragic and based on knowledge and contemplation. The tragedy of Faust resolutely assigns the primacy to action. ${ }^{95}$ Free will read as freedom is equivocal because the context in which it is used is not political freedom but moral and juridical freedom regarding the imputability of actions. ${ }^{96}$ The church fathers used 'it as a technical term to express the mastery of the will over actions in' 'the origin of evil and responsibility of $\sin ,{ }^{97}$ In that sense it is found for the first time 'referring significantly to the devil. ${ }^{98}$ Indeed per Agamben, God accuses Satan of accusation itself. ${ }^{99}$

For Agamben 'is an obvious fact' '[t]hat the law is defined as an articulation of violence and justice'. ${ }^{100}$ Agamben positions this definitive aspect of the law as a political theodicy - a justification of evil - stating that 'the law consists of essentially in the production of a permitted violence, which is to say in a justification of violence'. ${ }^{101} \mathrm{He}$ even references Kelsen's inclusion of the Sermon on the Mount's non-violence precept as also based on sanction, ${ }^{102}$ the same sermon that Weber analysed only to conclude that politicians 'must abide by its precise opposite lesson: '[y]ou shall use force to resist evil'. ${ }^{103}$ Agamben notes that this link of the law and sanction was considered as 'less than perfect' in Roman jurisprudence. ${ }^{104}$ This approach is therefore comparable to Weber's answer to the question: 'Can the ethical demands made on politics really be quite indifferent to the fact that politics operates with a highly specific means, namely, power behind which violence lies concealed'? ${ }^{105}$ This why Weber includes in this the startling observation that 'the politician must abide by the opposite commandment ["resist not him that is evil with violence"]: "You shall use force to resist evil, for otherwise you will be responsible for its running amok". ${ }^{106}$ Weber arrived at that conclusion by

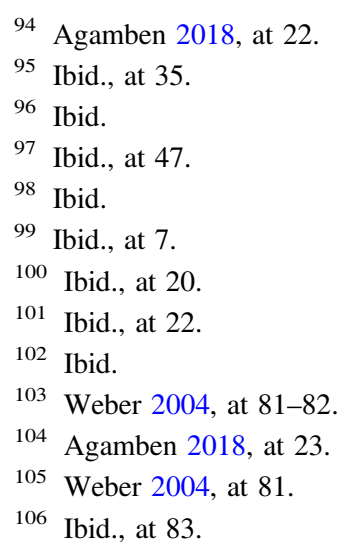


identifying and distinguishing an ethic of responsibility versus an ethic of conviction. While the former holds that 'a Christian does what is right and leaves the outcome to God' the latter provides that you must answer for the (foreseeable) consequences of your actions. ${ }^{107}$ What unites Weber and those that write in his wake is that violence is justified as being politically necessary particularly with regard to resisting violence and that this riddle is in the nature of a Faustian pact.

\subsection{Conclusion}

The Mungiki consciously utilise the etymological associations of their name to 'people' to promote a form of Kikuyu nationalism in a complex process of representation of the Kikuyu tribe onward to Kenyans as a whole and then all the way to Africa generally. This process of conflation is (but for defence counsel Khan's 'deal with the devil observation above) neither adequately identified nor captured using the mechanism of international criminal trials. This form of Mungiki populism further pushes the distinction between victim and victimiser right to the limit and even beyond. Mungiki's political and historical antecedents are based very much on control over women's bodies and sexuality, utilising both physical and structural forms of political violence as the springboard for their authority over the rest of society. This chapter began by noting that Mungiki literally means people and then went on to identifying the direct absence of 'people' in international law. It then followed that by looking how Mungiki's theory and practice of female circumcision was a political act of symbolic violence. That violence perpetrated by the Mungiki against the Kenyan State was then contextualised with regard to the law by reference to the literary trope of the Faustian pact. Given these complexities, prosecution whether domestic, hybridised or international, while necessary to redress the criminal violations committed, can only be one among the necessary responses to the political violence associated with Mungiki.

\section{References}

Agamben G (1998) Homo Sacer: Sovereign Power and Bare Life. Stanford University Press, Stanford

Agamben G (2000) Means Without End: Notes on Politics. University of Minnesota Press, Minneapolis

Agamben G (2005) State of Exception. University of Chicago Press, Chicago

Agamben G (2011) The Sacrament of Language: An Archaeology of the Oath. Stanford University

Press, Stanford

107 Ibid. 
Agamben G (2015) Stasis: Civil War as a Political Paradigm (Homo Sacer II, 2). Edinburgh University Press, Edinburgh

Agamben G (2018) Karman: A Brief Treatise on Action, Guilt, and Gesture, Stanford University Press, Stanford

Ahlberg BM, Njoroge KM (2013) 'Not men enough to rule!': politicization of ethnicities and forcible circumcision of Luo men during the postelection violence in Kenya. Ethnicity \& Health 18(5):454-468

Benjamin W (1978) "Critique of Violence", Reflections: Essays, Aphorisms, Autobiographical Writings. Harcourt Brace Javanovich, New York

Derrida J (1990) Force de Loi: La "Fondement Mystique de L'Autorite"/Force of Law: the "Mystical Origin of Authority". Cardozo Law Review 11(5-6):920-1046

Graf S (2017) To Regain Some Kind of Human Equality: Theorizing the Political Productivity of 'Crimes against Humanity'. Law, Culture and the Humanities. https://doi.org/10.1177/ 1743872115612326. Accessed 10 April 2019

Goethe JW (2001) Faust: A Tragedy: Interpretive Notes, Contexts, Modern Criticism, 2nd edn. W.W. Norton, New York

Harneit-Sievers A, Peters RM (2008) Kenya's 2007 general election and its aftershocks. Africa Spectrum 43(1):133-144

Hobbes T (2005) Leviathan (Richard Tuck ed). Cambridge University Press, Cambridge

Kagwanja PM (2005) Clash of Generations? Youth Identity, Violence and the Politics of Transition in Kenya, 1997-2002. In: Abbink J, van Kessel I (eds) Vanguards and Vandals. Youth, Politics and Conflict in Africa. Brill Publishing, Leiden

Kagwanja PM (2009) Courting genocide: Populism, ethno-nationalism and the informalisation of violence in Kenya's 2008 post-election crisis. Journal of Contemporary African Studies 27(3):365-387

Katumanga M, Cliffe L (2005) Armed violence and poverty in Nairobi: a mini case study for the Armed Violence and Poverty Initiative. Bradford Centre for International Cooperation and Security. https:// bradscholars.brad.ac.uk/bitstream/handle/10454/996/AVPI_Nairobi.pdf?sequence=1\&isAllowed=y. Accessed 10 April 2019

Kyle K (1997) The politics of the independence of Kenya. Contemporary British History 11(4):42-65

Lonsdale J (1990) Mau Maus of the Mind: Making Mau Mau and Remaking Kenya. The Journal of African History 31(3):393-421

Mockaitis T R (1992) Minimum force, British counter-insurgency and the Mau Mau rebellion: A reply. Small Wars \& Insurgencies 3(2):87-89

Mudde C, Kaltwasser CR (2013) The Oxford Handbook of Political Ideologies. Oxford Handbook Online. http://www.oxfordhandbooks.com/view/10.1093/oxfordhb/9780199585977.001.0001/ oxfordhb-9780199585977-e-026. Accessed 10 April 2019

Njambi WN (2004) Dualisms and female bodies in representations of African female circumcision. A Feminist Critique. Feminist Theory 5(3):281-303

Rasmussen J (2010) Outwitting the professor of politics? Mungiki narratives of political deception and their role in Kenyan politics. Journal of Eastern African Studies 4(3):435-449

Report of 'The Commission of Inquiry on Post Election Violence' (the Waki Commission)

Ruteere M (2008) Dilemmas of Crime, Human Rights and the Politics of Mungiki Violence in Kenya. Kenya Human Rights Institute. https://papers.ssrn.com/sol3/papers.cfm?abstract_id= 1462685. Accessed 10 April 2019

Schmitt C (2005) Political theology: four chapters on the concept of sovereignty. University of Chicago Press, Chicago 
Stringer K W (2014) “A Household Divided”: A Fragmented Religious Identity, Resistance and the Mungiki movement among the Kikuyu in Post-colonial Kenya. Dissertation Presented in Partial Fulfillment of the Requirements for the Degree Doctor of Philosophy in the Graduate School of The Ohio State University Graduate Program in History https://etd.ohiolink.edu/!etd. send_file?accession=osu1395764314\&disposition=inline. Accessed 14 April 2019

Wamue G (2001) Revisiting Our Indigenous Shrines though Mungiki. African Affairs 100(400):453-467

Weber M (2004) The Vocation Lectures. Hackett Publishing, Indianapolis

Wolfram R (2012) Preamble. In: Simma Khan D-E, Nolte G, Paulus A (eds) The Charter of The United Nations: A Commentary, $3^{\text {rd }}$ edn. Oxford University Press, Oxford 